\title{
Influence of Industrial Wastewater in Douala City on Growth, Chlorophyll and Cadmium Levels of Vigna unguiculata of Economic Importance
}

\author{
Priso Richard Jules ${ }^{1}$, Promesse-Ssie Mpahmadje Yves ${ }^{1}$, Biye Elvire Hortense ${ }^{2}$, \\ Idole Olenguena Florentine Aimée ${ }^{1}$, Taffouo Victor Desiré ${ }^{1}$, Din Ndongo ${ }^{1}$ \\ ${ }^{1}$ Departement of Botany, Faculty of Science, University of Douala, Douala, Cameroun \\ ${ }^{2}$ Departement of Botany, Faculty of Science, University of Yaounde I, Yaounde, Cameroun \\ Email address: \\ r_priso@yahoo.fr (P. R. Jules)
}

\section{To cite this article:}

Priso Richard Jules, Promesse-Ssie Mpahmadje Yves, Biye Elvire Hortense, Idole Olenguena Florentine Aimée, Taffouo Victor Desiré, Din Ndongo. Influence of Industrial Wastewater in Douala City on Growth, Chlorophyll and Cadmium Levels of Vigna unguiculata of Economic Importance. Ecology and Evolutionary Biology. Vol. 2, No. 5, 2017, pp. 87-95. doi: 10.11648/j.eeb.20170205.13

Received: August 22, 2017; Accepted: September 5, 2017; Published: October 12, 2017

\begin{abstract}
Over the world, biodiversity conservation issues related to environmental protection are vital. Douala is one of the cities where water pollution is important. Thus, a comparative study has been carried out on some growth parameters (germination, leaf surfaces, length of stem, number of leaves), chlorophyll and cadmium contents in leaves of Vigna unguiculata grown at the vicinity of three polluted water discharged sites (Azur, Industrial Zone of Bonaberi and Abattoir of Bonendale) and a non-polluted site (control). The methodology consisted of sowing cowpea in both polluted and unpolluted sites and then the growth parameters were taken every two days for six weeks during which chlorophyll in the leaves was measured after thirty days. Moreover, the degree of pollution of waste water was analyzed in the laboratory based on physicochemical parameters. The results show that plant growth is abnormal in contaminated sites (Industrial Zone of Bonaberi, Azur and Abattoir of Bonendale and the average chlorophyll $(\mathrm{a}+\mathrm{b})$ of the leaves is 36.32 for the control and 11.23; 5.26; 17.42 respectively for polluted sites (Azur, Industrial Zone of Bonabéri and Abattoir of Bonendale). These values are significantly different. Plants in the control site concentrate less Cadmium than those in polluted sites. The Cadmium maximum absorption is observed in a site located in the Industrial Zone of Bonaberi with nearly six times the value of the control.
\end{abstract}

Keywords: Control, Environmental Pollution, Germination, Industrial City, Littoral Zone, Plant Leaves, Polluted Water

\section{Introduction}

The preservation and conservation of the environment is an initiative to emphasize because due to industrial revolution, man's aggression against nature has become very significant. In developing countries, the environmental problem is more acute in terms of the imbalance between natural resources (water, soil, subsoil etc.) and population growth ([1]; [2]; [3]). The situation is accentuated by the absence of any preventive measures to reduce the degradation of the environment physically or biochemically However, some industries have opted for products that are environmentally friendly.

The city of Douala, considered the economic capital of
Cameroon, converges almost all the national industrial production system. The industries in and around this city have become veritable environmental vandals that discharge their effluents (solid or liquid) directly into nature without prior treatment or precaution [4]. Indeed, very few industrial units are equipped with treatment plants, although Law No. 96-12 of 05 August 1996 on environmental management in Cameroon stipulates in its article 42 section F of Chapter 5 that: "Waste must be treated in an environmentally sound manner in order to eliminate or reduce its adverse effects on human health, natural resources, fauna and flora and on the quality of Environment in general."

The quality of the waste water can be monitored either by physico-chemical analysis or biological analysis ([5]; [6]; [7]). The biological analysis makes it possible to identify the 
disturbances and their effects on animals and plants in situ while the physicochemical analysis contributes to characterize the origin of disturbances on pollutants nature [8].

Some species from families such as Commelinaceae have already been used in Cameroon as indicators of the quality of aquatic environments [6]. These results have highlighted the sensitivity of some species to characterise the environment as the risks incurred by plants with pollution may vary. Some plants are very resistant to pollution while others are sensitive and may disappear. The effects are, for example, problems of germination, growth, chlorosis and leaf necrosis.

It is now indisputable that the industrialization of Africa, particularly Cameroon, must proceed rapidly in order to satisfy the basic needs of its inhabitants [9]. Nevertheless, this industrialization ought to be carefully planned to avoid serious environmental problems. The AZUR-Yassa, Industrial Zone of Bonaberi and the Abattoir of Bonendale are among the polluted sites of the city of Douala. Industries seen in these sites do not possess wastewater treatment plants and discharge their effluents directly into the environment without prior treatment. These toxic effluents could contaminate the potable water by infiltration and damage the food chain.

In addition, environmental perturbations can reflect the biological quality of the environment [8]. The latter provides fast results and amplifies discrete pollutions. It integrates spatio-temporal variability by the constant presence of organisms and reflects the impact of pollutant on human health [10]. The vegetation thus more easily integrates sudden or occasional changes in its environment [11]. The problem here is the quality of products derived from poorly controlled urban agriculture by inhabitants of Douala city. This farming method is sometimes motivated for subsistence and is carried out in small spaces such as in Azur, Bonaberi and Bonendale despite the dangers due to the quality of the environment which is often altered by various pollutants. Some crops such as beans, maize and groundnuts have been reported in the vicinities of the Bonendale slaughterhouse and the Cameroon distillery at Boadibo [6-12].

The aim of this work was to emphasize on the effects of water pollution on the crop $V$. unguiculata in order to sensitize urban farmers who, in the interest of survival, sometimes cultivate in various environments despite the risks incurred on the species as well as consumers of this type of culture.

The specific activities carried out in various environments include the:

- monitoring of the evolution of some growth parameters (germination rate, number of leaves and leaflets per plant, length of stem, leaf area);

- determination of chlorophyll content in leaves;

- evaluation of the content of some heavy metals in leaves of plants;

- measure of some physico-chemical parameters of waters from various sites.

\section{Materials and Methods}

\subsection{Study Area}

Douala, located at $30 \mathrm{~km}$ from the sea is considered the seaport city, with an impressive industrial and commercial fabric. It occupies about 18000 ha of land with more than 2 million inhabitants and it is subdivided into five urban districts. The sites were selected after prospecting 80 companies in the city of Douala. For this study, three polluted sites were selected (Azur, Industrial zone of Bonaberi and Abattoir of Bonendale).

The climate of Douala indicates a long rainy season from March to November and a short dry season from December to February marked, especially on the coast by significant precipitation. The average daily temperatures had been collected each month for 30 years by the Douala City Council (1984 to 2014) and the average monthly temperature varies from $24.8^{\circ} \mathrm{C}$ in July and August to $27.7^{\circ} \mathrm{C}$ in February with an annual average of $26.4^{\circ} \mathrm{C}$.

\subsection{Soils and Vegetation}

The soils of Douala are generally sandy with a low water holding capacity. However, other types of ferralitic soils formed on the diversity of the present bedrock (basalt and gneiss) sometimes with clay content are observed. These soils are better suited to agriculture because of their chemical properties. The warm and humid climate of the city of Douala is conducive for the luxuriant development of dense forest, mangroves and some vegetable crops that regress the advancement of urban development.

\subsection{Location of the Different Sites}

During this work, the studies were carried out on four (04) sites among which three polluted and one unpolluted sites.

\subsubsection{Site 1: Azur}

The azur site is located at the East entrance of Douala called Yassa with GPS coordinates of $004^{\circ} 02^{\prime} 13.0^{\prime} \mathrm{N} 009^{\circ}$ 45 ' $37.4^{\prime}$ 'E. With respect to the elevation, this site is $18 \mathrm{~m}$ above sea level.

The study was conducted along the channel downstream of wastewater discharge of the company AZUR S. A which is an agro-industry producing soap, vegetable oils and spaghetti.

\subsubsection{Site 2: Industrial Zone of Bonaberi}

This site is located at the West entrance of Douala in the premises of the MAGZI, a French acronym meaning "Mission d'Amenagement et de Gestion des Zones Industrielles". The work was carried out on the wastewater collecting channel of all the companies in the Bonaberi industrial zone which dump its waste directly into the Wouri. The GPS coordinates here were $004^{\circ} 03^{\prime} 52.9^{\prime \prime} \mathrm{N}$ and $009^{\circ} 45^{\prime} 54.1^{\prime \prime} \mathrm{E}$ and $3 \mathrm{~m}$ above sea level.

\subsubsection{Site 3: Abattoir of Bonendalè}

It is also located at the West entrance of the city of Douala. 
The outlet in which the work was carried out is the channel collecting waste from the slaughterhouse, essentially consisting of cow burses and the blood of slaughtered animals drained downstream. The GPS coordinates indicated that the study site was at $004^{\circ} 06^{\prime} 37.1^{\prime \prime} \mathrm{N}, 009^{\circ} 38^{\prime} 45.2^{\prime \prime} \mathrm{E}$ and at $12 \mathrm{~m}$ above sea level.

\subsubsection{Site 4: Control}

The control site was set up in an unpolluted area located at the east entrance of the city of Douala in the so-called 'Village' area along a river that collects rainwater from various parts of the city. Its geographical coordinates were $03^{\circ} 59^{\prime} 23.9^{\prime \prime} \mathrm{N}, 009^{\circ} 45^{\prime} 54.1^{\prime \prime} \mathrm{E}$ and $08 \mathrm{~m}$ above sea level.

\subsection{Planting Process}

The seeds of Vigna unguiculata were washed with $3 \%$ bleach and then rinsed with distilled water before they were put in the soil in the various sites of study. In order to determine the germination potential of the sampled seeds, they were placed in a jar in the laboratory under natural conditions and those that germinated were counted every two days. This method permitted to study the action of the environment on the germination of the seeds. Prior to cultivation, the field preparation consisted of preliminary weeding and making of ridges. The seeds of Vigna unguiculata were then sowed with hoes in groups of 3 or 4 separated by a distance of $50 \mathrm{~cm}$ along the ridges. The growth of the young plants was monitored for six weeks during which the different assays were carried out.

\subsection{Measurement of Physico-Chemical Parameters of Water}

With the exception of $\mathrm{pH}$, conductivity and temperature that were measured in situ, other parameters such as Biological Oxygen Demand for 5 days $\left(\mathrm{BOD}_{5}\right)$, cadmium, phosphate, and nitrate were analyzed in the laboratory. Water sampling was carried out at all four sites (three polluted sites and control) in the plots where Vigna unguiculata was grown. The samples were taken at the fourth week of planting between 08:00 and 11:00 and then stored in labeled polyethylene bottles of one liter capacity and kept in icefilled boxes. These water bottles were subsequently transported to the Soil, Plant, Fertilizer and Water Analysis Laboratory (LASPEE) where parameters such as BOD5, nitrate, phosphate, heavy metals (Cadmium) were analyzed.

\subsection{Determination of Chlorophyll Content}

\subsubsection{Experimental Techniques}

The leaves of Vigna unguiculata were harvested after four weeks of cropping at all four study sites. The plant material was then taken to the Laboratory of Botany at the University of Douala where it was then washed, wiped and then $0.80 \mathrm{~g}$ of fresh material was weighed using a sororium brand balance, serial number TE612 with precision $10-2$. This plant material was ground in a porcelain mortar with fine sand previously washed, sterilized and dried to facilitate grinding. Ten milliliters of $80 \%$ acetone were then added to the mixture, the extract was filtered and the supernatant was then recovered. Thus, the desired chlorophyll was contained.

\subsubsection{Revelation Techniques}

The apparatus used for reading was the spectrophotometer which was first calibrated to zero absorbance using acetone $(80 \%)$. The filtration extract was then poured into a pillbox and placed in the spectrophotometer for reading. The reading was carried out at $645 \mathrm{~nm}$ and $663 \mathrm{~nm}$ corresponding respectively to $710 \mathrm{~nm}$ and $600 \mathrm{~nm}$ absorption wavelengths of chlorophyll. Concentrations in $\mathrm{mg} / \mathrm{l}$ of chlorophyll solution were obtained according to [13] using the following formulae: Chlorophyll $\mathrm{a}=12.7 \mathrm{x}-2.69 \mathrm{x}$; Chlorophyll $\mathrm{b}=$ $22.9 x-4.68 y$; Chlorophyll $\mathrm{a}=20.21 \mathrm{x}+8.02 \mathrm{y}$.

\subsection{Measurement of Plant Growth Parameters}

After planting, as stated above, plant growth parameters were monitored every two days for six weeks while germinated seeds were counted every day to determine the germination rate at each site. The length of the entire plant was also measured using a sliding foot; the number of leaves and leaflets evaluated and on the largest leaves of each plant, the length (L) was measured as well as the width (1) using a graduated scale.

\subsection{Calculation of Growth Parameters}

-Germination rate $(\%)=$ (number of germinated seeds $/$ number of total seeds sown) $x 100$

-The foliar area (S) was calculated from the measurements taken in the field, in particular the length (L) and the width (l) according to the relationship:

$$
\mathrm{S}=2 / 3(\mathrm{~L} \times 1)
$$

\subsection{Statistical Analysis}

The processing of the data was carried out the Excel spreadsheet of the Microsoft Office 2007 package. The analysis of the data obtained by the statistical analysis software Grapad Prism 5. The ANOVA one way test was used for the analysis of variance linked to a factor or growth parameter at the 5\% threshold and then a comparison of mean 2 to 2 of Dunnette yielded the results.

\section{Results}

\subsection{Aspect of Vigna unguiculata in the Studied Sites}

The plant shoots obtained in various environments have remarkable physical differences; specifically the plants grown around the slaughterhouse (Abattoir) and at the control site appeared darker and showed normal growth compared to those of the other two sites (Azur and MADZI of Bonaberi) which showed a very high dwarfism as well as a very perceptible chlorosis. 


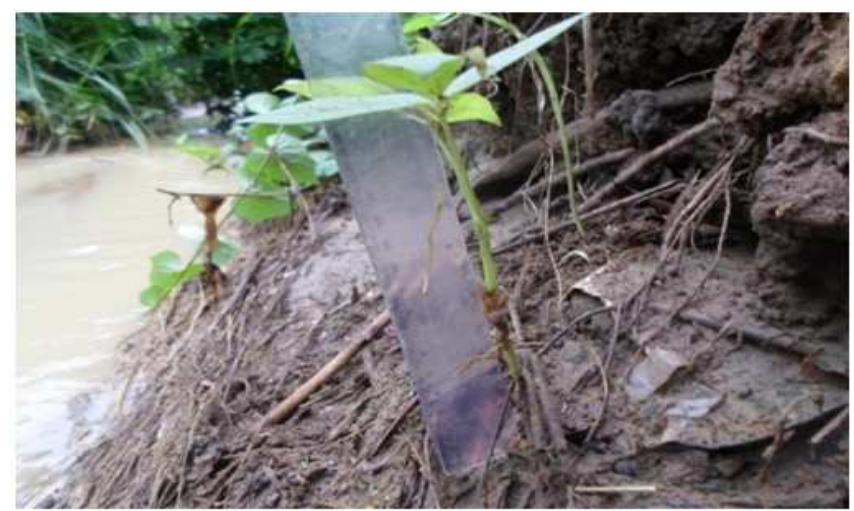

A1

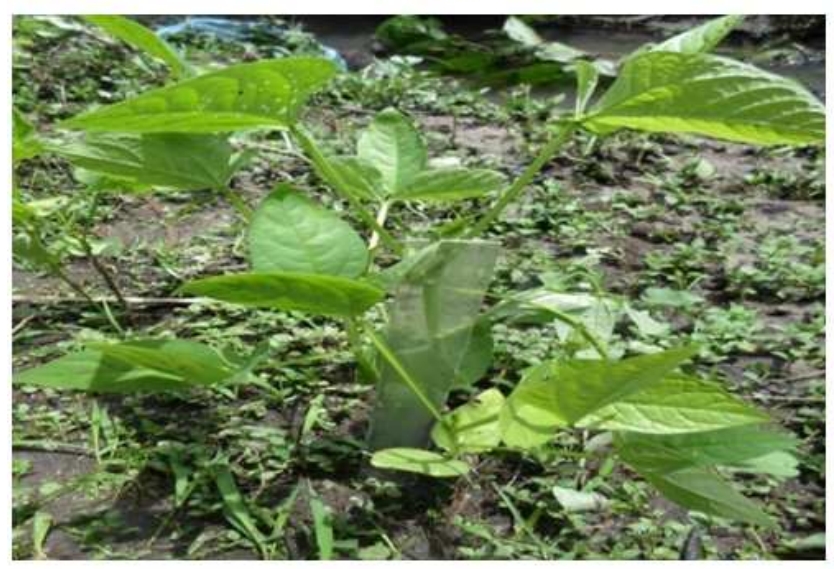

A3

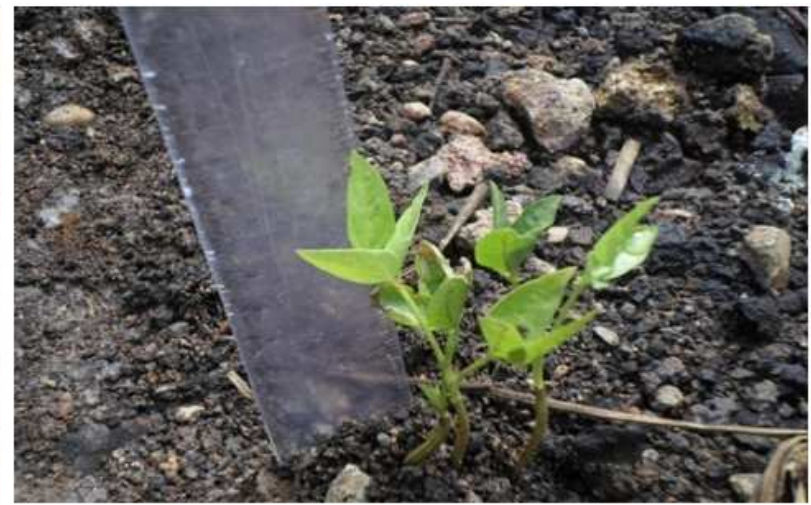

A2

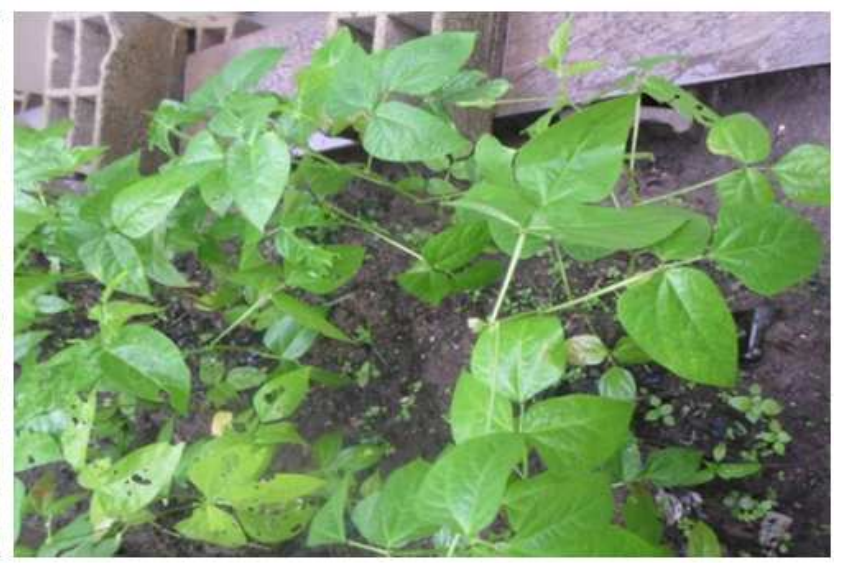

A4

Figure 1. Appearance of Vigna unguiculata grown: A1: at the Azur site after 3 weeks showing foliar chlorosis and dwarfism; A2: at Z. I of Bonaberi cultivated at Azur site after 3 weeks with very advanced foliar chlorosis and dwarfism; A3: at the Bonendale slaughterhouse A4: Aspect at control site showing good pigmentation and normal development.

\subsection{Physicochemical Parameters}

Some physicochemical parameters of water at various sites were obtained. $\mathrm{pH}$ values varied from $07.67 \pm 0.020$ to 09.35 \pm 0.006 as seen in Table 1. Cadmium and $\mathrm{DBO}_{5}$ high values were seen at Azur.

Table 1. Some physicochemical parameters of the water in the environment.

\begin{tabular}{|c|c|c|c|c|}
\hline $\begin{array}{ll}\text { Parameters } & \text { Stations } \\
\end{array}$ & Azur $n=3$ & Z. I Bonabéri n=3 & Abattoir $n=3$ & Control $n=3$ \\
\hline $\mathrm{pH}$ & $09.35 \pm 0.006$ & $08.12 \pm 0.010$ & $07.67 \pm 0.020$ & $07.35 \pm 000$ \\
\hline Temperature $\left({ }^{\circ} \mathrm{C}\right)$ & $33.30 \pm 0.006$ & $30.10 \pm 0.006$ & $30.10 \pm 000$ & $29.40 \pm 0.006$ \\
\hline COND $(\mu \mathrm{S})$ & $85.77 \pm 0.020$ & $75.25 \pm 0.005$ & $205.01 \pm 0.010$ & $46.69 \pm 0.300$ \\
\hline Cadmium $(\mu \mathrm{g} / \mathrm{l})$ & $01.56 \pm 000$ & $00.45 \pm 2.310$ & $03.15 \pm 0.006$ & $00.03 \pm 0.006$ \\
\hline Nitrates (mg/l) & $04.55 \pm 0.006$ & $13.18 \pm 0.025$ & $11.68 \pm 0.006$ & $01.23 \pm 0.006$ \\
\hline $\mathrm{PO}_{4}^{2-}(\mathrm{mg} / \mathrm{l})$ & $00.80 \pm 0.006$ & $00.218 \pm 0.006$ & $00.318 \pm 0.006$ & $00.021 \pm 000$ \\
\hline
\end{tabular}

\subsection{Chlorophyll Level in Leaves of Vigna unguiculata}

Chlorophyll $\mathrm{a}, \mathrm{b}$, and $(\mathrm{a}+\mathrm{b})$ have been found in the leaves of $V$. unguiculata and the values of these chlorophyll contents show that they varied according to environment and are lower in polluted sites.

The chlorophyll $(\mathrm{a}+\mathrm{b})$ content is very high in the control with value $36.32 \pm 5.44 \mathrm{mg} / \mathrm{l}$. The lowest value was founded at the Industrial Zone of Bonaberi, at $5.26 \pm 5.75 \mathrm{mg} / 1$, while the other sites indicate $17.42 \pm 5.81 \mathrm{mg} / 1$ and $11.23 \pm 5.39$ $\mathrm{mg} / \mathrm{l}$ at the slaughterhouse and Azur respectively (Figure 2).

The highest value, $16.37 \pm 0.65 \mathrm{mg} / \mathrm{l}$, for chlorophyll a is also found at the control site (Figure 2 B1). The smallest value $6.83 \pm 9.63 \mathrm{mg} / \mathrm{l}$ was found at the Industrial Zone of Bonaberi; and intermediate values at the slaughterhouse $13.34 \pm 5.17 \mathrm{mg} / \mathrm{l}$ and at Azur 7.27 $\pm 1.91 \mathrm{mg} / \mathrm{l}$.

The highest value for chlorophyll $\mathrm{b}$ was observed around the slaughterhouse $(17.86 \pm 8.10 \mathrm{mg} / \mathrm{l})$ and the smallest at Azur $(8.77 \pm 5.67 \mathrm{mg} / \mathrm{l})$. 


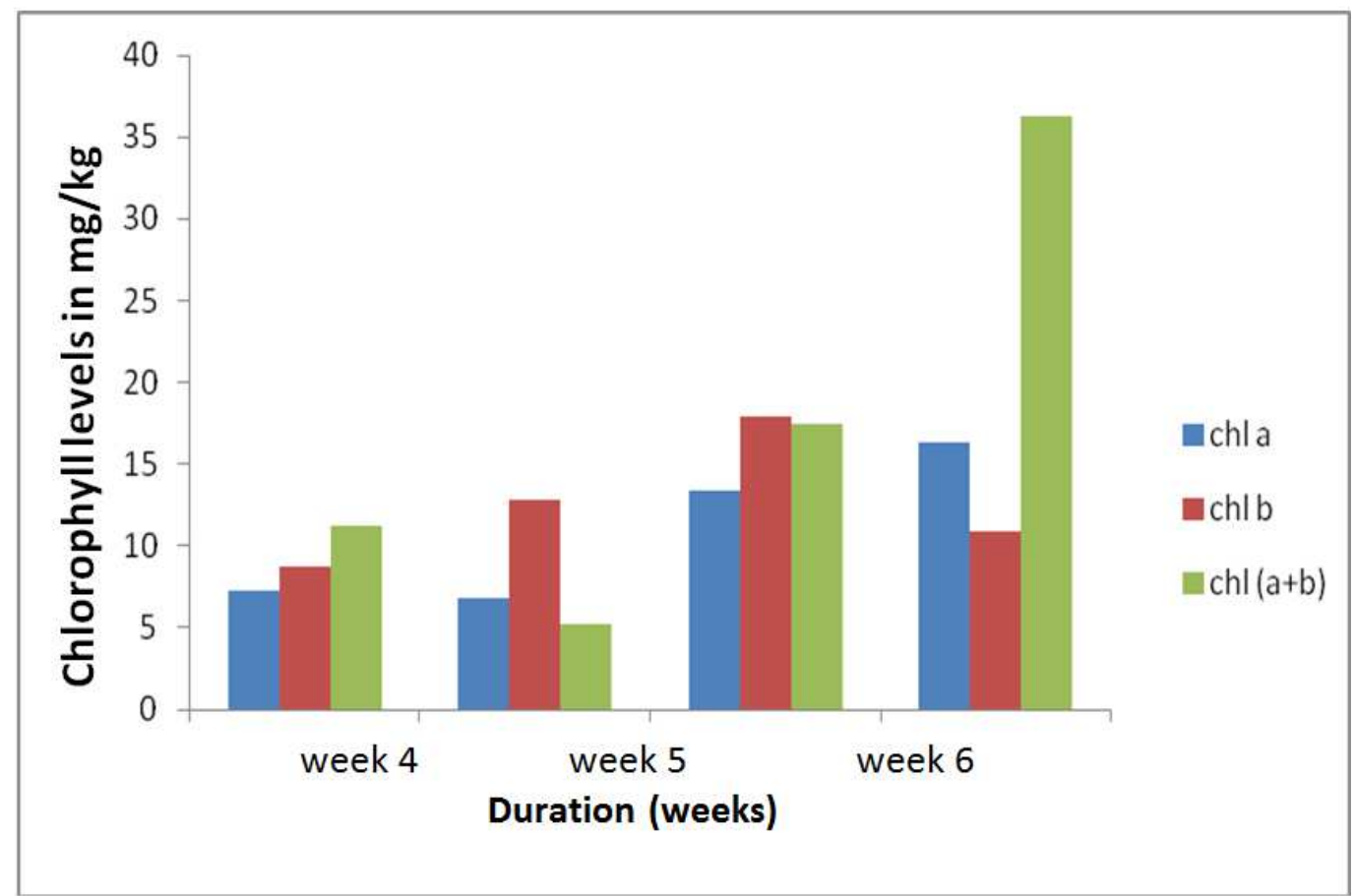

Figure 2. Chlorophyll a, chlorophyll $b$ and chlorophyll $(a+b)$ in the leaves of Vigna unguiculata in the different sites studied after 30 days.

\subsection{Cadmium Content in Plants}

The comparison of the cadmium content in the leaves of the plants showed that the plants of the Industrial Zone of Bonaberi had more cadmium $(0.0067 \mathrm{mg} / \mathrm{kg})$ and the plants of the control site are those with the lowest $(0.0010 \mathrm{mg} / \mathrm{kg})$. The plants in the slaughterhouse contain $0.0034 \mathrm{mg} / \mathrm{kg}$ and those at Azur $0.0022 \mathrm{mg} / \mathrm{kg}$ (Figure 3).

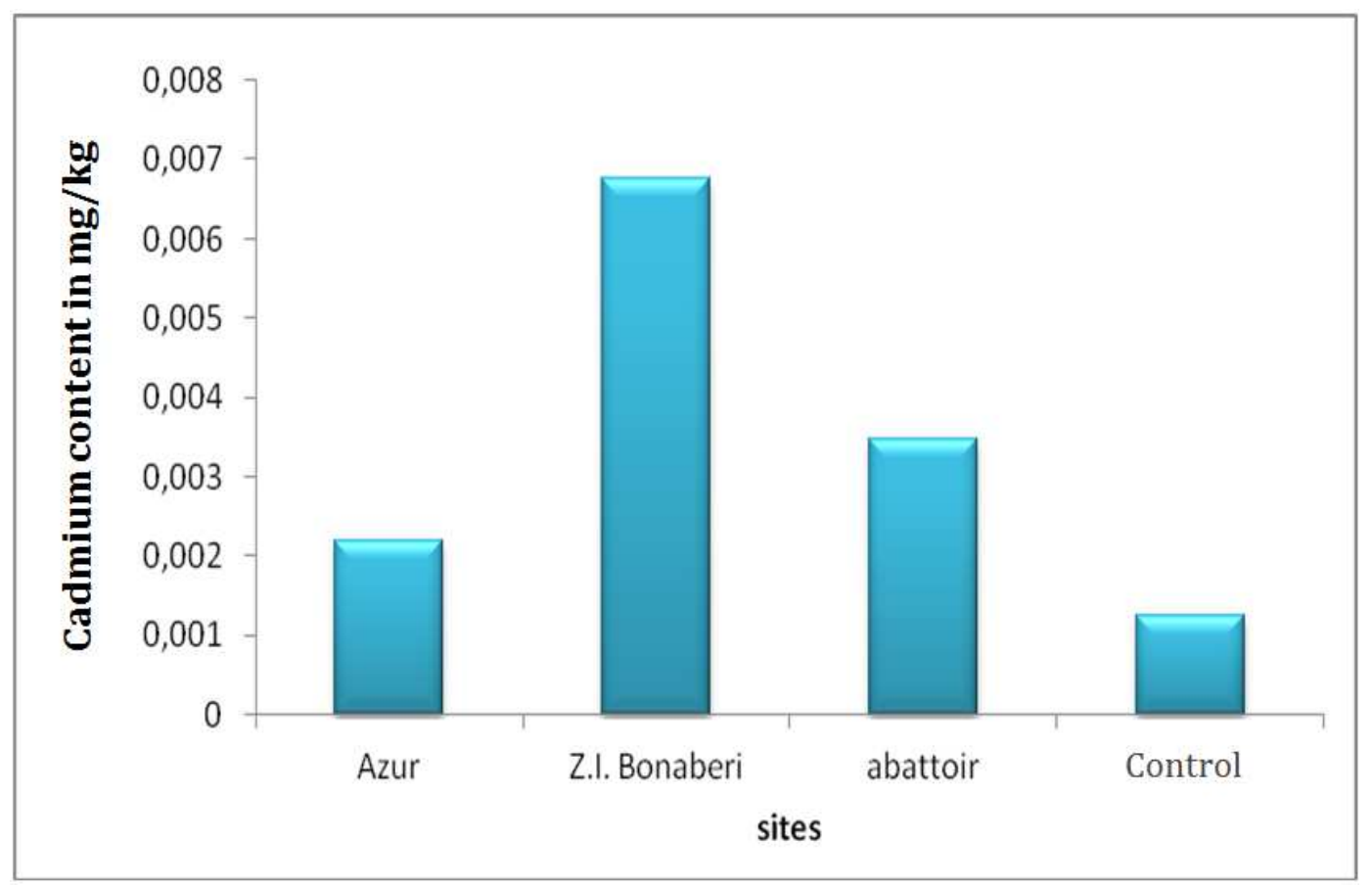

Figure 3. Cadmium content in the leaves of Vigna unguiculata in the different sites studied after 30 days.

\subsection{Growth Parameters}

\subsubsection{Germination Rate and Germination Time}

It was found that there was a very marked difference in the germination rate between various sites, and also with results obtained in the laboratory. The highest rate of germination was seen in the control $(61.70 \%)$ while the lowest was seen in Bonaberi Industrial Zone (Table 2). 
Table 2. Germination rate and germination time in various sites of study.

\begin{tabular}{lllll}
\hline & Laboratory & Control & Z. I Bonabéri & Azur \\
\hline Number of seeds sown & 180 & 180 & 180 & 180 \\
Seed numbers germinated & 170 & 111 & 93 & 180 \\
Germination rate (\%) & 94.44 & 61.70 & 50.86 & 106 \\
Duration of germination (days) & 10 & 8 & 11 & 59 \\
\hline
\end{tabular}

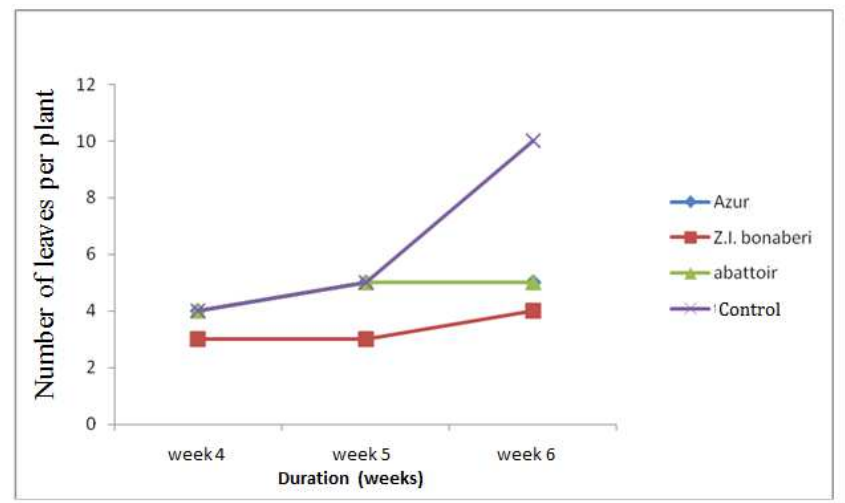

$\mathrm{C} 1$

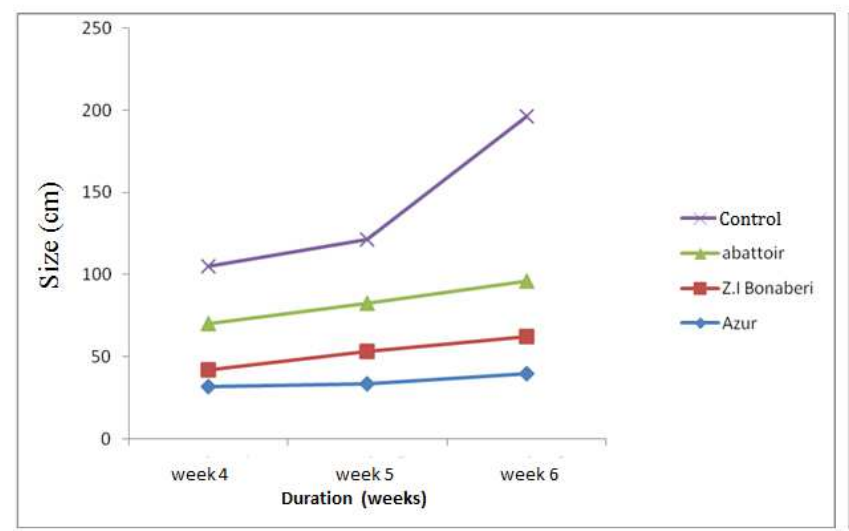

C3

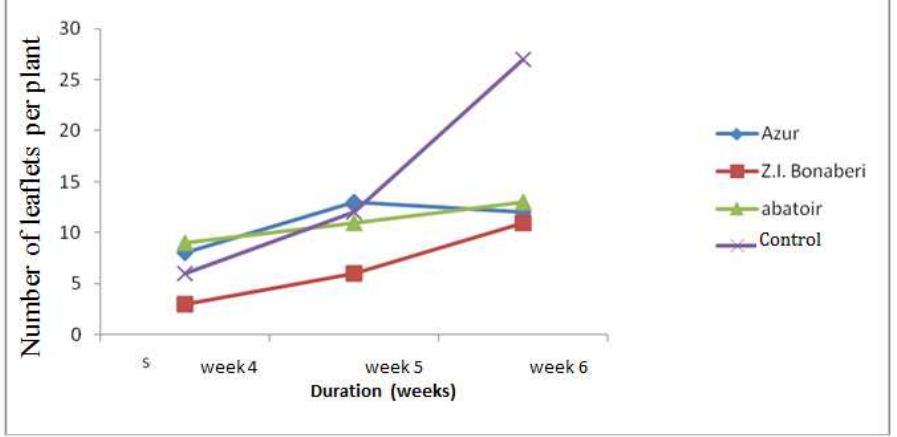

$\mathrm{C} 2$

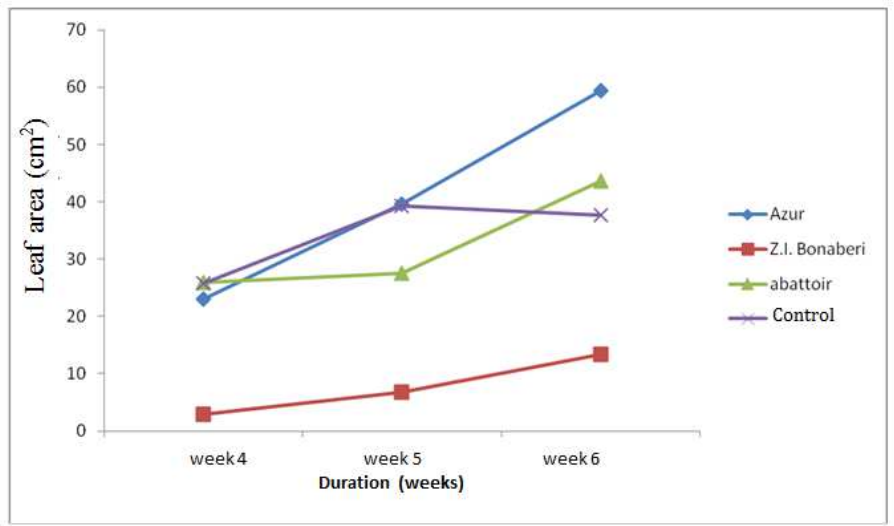

$\mathrm{C} 4$

Figure 4. Trends of some growth parameters: $C 1=$ change in the number of leaves per plant over time; $C 2=$ evolution of the number of folioli per plant over time; $C 3=$ evolution of plant size over time; $C 4=$ evolution of leaf area with time.

\subsubsection{Leaf Area}

The leaf area at the 4th week was highest in the control $\left(25.83 \mathrm{~cm}^{2}\right)$ followed by the slaughterhouse $\left(25.93 \mathrm{~cm}^{2}\right)$ and Azur $\left(23.06 \mathrm{~cm}^{2}\right)$. However, the smallest value was encountered at the Industrial Zone of Bonaberi $\left(2.88 \mathrm{~cm}^{2}\right)$. At the 5 th week the highest values were reported respectively at Azur $\left(39.66 \mathrm{~cm}^{2}\right)$, control $\left(39.29 \mathrm{~cm}^{2}\right)$ and slaughterhouse $\left(27.60 \mathrm{~cm}^{2}\right)$ and the lowest found at the Industrial Zone of Bonaberi $\left(5.68 \mathrm{~cm}^{2}\right)$. The 6 th week shows results that are somewhat different from the previous ones with a maximum leaf area at Azur $\left(59.4 \mathrm{~cm}^{2}\right)$, then the abattoir $\left(43.58 \mathrm{~cm}^{2}\right)$ and finally the control $\left(37.62 \mathrm{~cm}^{2}\right)$. Industrial Zone of Bonaberi is the site with the minimum leaf area of $13.29 \mathrm{~cm}^{2}$ (Figure 4 C4).

\subsubsection{Length of Stems}

Data from stem length measurements show that at week 4, the longest stem was obtained in the control site $(35.03 \mathrm{~cm})$ and the shortest at the Industrial Zone Bonaberi $(9.76 \mathrm{~cm})$.
Intermediate values are found in Azur $(32.00 \mathrm{~cm})$ and Abattoir $(28.54 \mathrm{~cm})$. During the 5th week, the classification was maintained with the stem length in the control site at $39.06 \mathrm{~cm}$; in Azure at 33.64cm; Abattoir $29.54 \mathrm{~cm}$ and Industrial Zone of Bonaberi $19.4 \mathrm{~cm}$. The observation of the 6th week attested a large peak at the control site $(99.06 \mathrm{~cm})$ which is five-fold that of the Industrial Zone of Bonaberi $(22.53 \mathrm{~cm})$ and the other sites have values of $34.03 \mathrm{~cm}$ at the slaughterhouse and $39.58 \mathrm{~cm}$ to Azur (Figure $4 \mathrm{C} 3$ ).

\subsubsection{Number of Leaves Per Plant}

The number of leaves per plant showed similarity between the Azur and Slaughterhouse sites at the 4th, 5th and 6th week, which were respectively $3 ; 5$ and 5 averages in leaves. The control showed an abrupt increase in the 6th week as in the 4th week, the leaf average was 4; in the 5th week, it was 5 and in the 6th week it became 10. The I. Z. Bonaberi showed a slight increase in the leaf number with 3 leaves/plant at the 4 th week; 3 also at the 5 th and 4 at the 6 th 
week. Moreover, based on this result, it is the site with the smallest number of leaves, contrary to the control that showed the highest number (Figure 4 C1).

\subsubsection{Number of Leaflets Per Plant}

The number of leaflets per plant at the Slaughterhouse was the highest of the four sites at the 4th week (04 leaflets/plant). The Industrial Zone site of Bonaberi was the site with the lowest number of leaves during the same week (03 leaflets/plant) then the control (06 leaflets/plant) and Azur (09 leaflets/plant). At the 5th week, the highest value was reported in Azur (13 leaflets/plant) followed by the control (12 leaflets/plant) and the lowest in Abattoir (11 leaflets/plant) and I. Z. Bonaberi (06 leaflets/plant). The 6th week was very different from the first two sites where the highest value was reported at the control site (27 leaflets/plant), then, at the Slaughterhouse (13 leaflets/plant) and Azur (12 leaflets/plant). Similarly, the lowest value was reported at the Bonaberi Industrial Zone with 11 leaflets/plant (Figure 4 C2).

\section{Discussion}

\subsection{Impact of Environmental Condition on Chlorophyll Content in the Plant}

The color of the leaves is linked not only to chlorophyll levels, but also to the index of damage also referred to as index of degeneration of the plant. According to [6] it reflects the degree of sensitivity of plants to pollutants resulting in their response to changes in the environment observed through chlorosis, necrosis and leaf fall. The results obtained based on the chlorophyll content of Vigna unguiculata are in agreement with those of [12]. In his work, chlorophyll $(a+b)$ levels in waste media are lower than chlorophyll levels in less polluted environments as the level of chlorophyll in the leaves of a plant reflects its degree of sensitivity to pollutants. In this regard, [14] has shown that heavy metals affect the accumulation of chlorophylls by influencing the different reactions leading to their synthesis. Another hypothesis would be that the metals could have prevented the iron, indispensable for the manufacture of chlorophyll from penetrating into the plant.

According to [15], phytotoxic pollutants such as sulfur dioxide, $\left(\mathrm{SO}_{2}\right)$, once in the leaf of the plants, destroy chlorophyll and disrupt photosynthesis, causing a reduction in plant growth. For the inhibition of chlorophyll synthesis, organic pollution (Slaughterhouse) would be less dangerous than chemical pollution (Azur and Bonaberi Industrial Zone), where the effects of heavy metals will affect the different chemical reactions leading to this synthesis. A nonsignificant decrease in chlorophyll $a$ and $b$ between the control and the slaughterhouse sites was observed for a confidence interval of 0.95 (p-value $>0.05$ ) while a slight decrease was observed at the Abattoir and Azur (p-value $<0.05$ ). Between the control and Azur, a very significant drop (p-value $<0.0001$ ) was obtained.

\subsection{Impact of Physico-Chemical Parameters}

The measured parameters showed that most of the values were below the detection threshold. These values attested the relative discretion of the pollutions induced by physicchemical characteristic in the various sites studied [16]. The very basic $\mathrm{pH}$ at Azur (9.35) and Industrial Zone of Bonaberi (8.12) indicates that the threshold of tolerance for plants begins to be crossed [17]. At these values, certain neutral or acidic enzymes are disrupted or inhibited with this disorganization leading to consequences on the growth of plants.

Temperature analysis showed that the highest was observed at Azur $\left(33.3^{\circ} \mathrm{C}\right)$ and the lowest at the control site $\left(29.4^{\circ} \mathrm{C}\right)$. This high temperature could be explained by the discharge of warm water from Azur Company, which would modify the chemical reactions. Thus, the enzymatic activity can be inhibited or modified since the latter has a tolerance threshold (acid, neutral or basic). The imbalance of the environment can also be manifested by morphological and physiological variations [18].

Cadmium, which was one of the heavy metals present in industrial discharges. This trace element was strongly present at the slaughterhouse $(3.15 \mathrm{mg} / \mathrm{kg})$ and very weak at the control (0.03), suggesting that the plants to be grown in the slaughterhouse site will be poisoned by this heavy metal. This can be explained by the presence in the water of hydrocarbons and phosphate pollutants. At high concentrations, this metal is toxic to plants because it inhibits their metabolism and photosynthesis [19]. The degree of oxygenation and variation in the composition of the organic matter of water can be measured by $\mathrm{BOD}_{5}$ or COD. These values were between 37.75 in Azur and 12.54 at the control site indicating that there was a strong activity of soil microorganisms at Azur, which justified the richness of the medium in nitrate which will make heavy metals like Cadmium $\left(\mathrm{Cd}^{2+}\right)$ mobile and bio-available. [20]. had similar result in Kribi-Cameroun while investigating the impact of waste water on biodiversity.

There was also high electrical conductivity at the Abattoir. These values indicate that the water discharge from this site is very rich in dissolved solids like Phosphate, Calcium, Sodium and Nitrate [21]. These was confirmed by the very high proportions of Nitrate and Phosphate at the Slaughterhouse site respectively 11,680 and 0,318 and were the highest in the four sites which implies that the plants developing in these sites were strongly enriched in mineral salts. Nitrate as well as phosphate is one of the electrolytes representing the forms in which plants are generally able of absorbing biogenic elements such as phosphorus and nitrogen [22].

The nitrate concentration of water at the sites studied varies between $1.23 \mathrm{mg} / \mathrm{l}$ for the control and $13.18 \mathrm{mg} / \mathrm{l}$ for Industrial Zone Bonaberi. The high concentration of nitrate in this industrial zone is undesirable to man and the environment. Also, this high content may cause acidification unbearable to plants. [23] reported that plants containing too 
much nitrates do not flower well (decrease in productivity of fruit and seeds). Moreover, the amount of phosphates varied according to sites with the Azur site having the highest phosphate content $(0.8 \mathrm{mg} / \mathrm{l})$ and the lowest content was observed at the control site. One reason for the abundance of this element in natural waters was the frequent use of phosphate-rich products (soap and fertilizers). Phosphate and nitrate were a serious cause of water contamination, causing the phenomenon of dystrophication which results in the death of fish and other organisms by asphyxiation [24].

\subsection{Cadmium Content in Plant Leaves}

Cadmium levels in plant leaves were very high in the Bonaberi Industrial Zone site. This high content showed that plants grown in this area are real poisons for humans [25]. Of the four sites, the discharged water from the slaughterhouse contained more Cadmium but in the leaves of plants, this was not the case. This may be due to the fact that in one of the two sites, contamination by pollutants was a periodic phenomenon which did not coincide with the sampling time of our sample of water to be analyzed.

\subsection{Growth Parameters}

There was a difference in germination rates at the laboratory and the control probably because some germinated seeds did not surfaced due to certain water or toxic conditions of the environment. This rate is even lower in Azur and Industrial Zone of Bonaberi sites. The almost normal growth of Vigna unguiculata at the Abattoir reflects the high concentration of phosphate and nitrate from industrial wastewater. The strong dwarfism observed at the Industrial Zone of Bonaberi and Azur was due to the various alteragens which disturb the metabolism of the plant or the insufficient availability of phosphate and nitrate. Statistical analysis showed a significant difference between all the sites for different weeks and the control site had a plants with the longest stem length than the others during the whole experiment except the 5 th week when plants encountered in Azur sites and control remained unchanged.

Reduction of leaf size in the site of Azur can be attributed to industrial wastewater with increase in temperature, also, alteration or a variation in $\mathrm{pH}$ which causes chlorosis and necrosis on the leaves. The comparison of polluted sites with the control site showed a significant difference ( $p$-value $<0.001)$ between the control site and the Bonaberi Industrial Zone at the 4 th and 5 th weeks. At the 6 th week, the difference becomes very perceptible between the control and Industrial Zone of Bonaberi but also between the control and Azur (p-value $<0.0001$ ). When a crop in an urban area is produced on a polluted site, there is reduction in growth parameters, thus a reduction in agricultural yield within an equal area of polluted compared to unpolluted sites. In this way, revenues will also be different.

The results clearly showed that the number of leaves of $V$. unguiculata varied from one site to another over time. Indeed, for polluted sites, the fewer number of leaves and leaflets is very perceptible, contrary to the control site where the number is quite high. [26] showed that in the Biyem-Assi purification system, the number of leaves of Pistia stratiotes increased when passing from the B1 basin which was the most polluted to the less polluted B7 basin. The statistical analysis on the number of leaves and leaflets showed that at the 4th week, the Industrial Zone of Bonaberi and the control showed a significant difference. Only Bonendale did not differ significantly with the control at the 5 th week but the difference would be more noticeable. In the 6th week, the control was different from all other sites studied. A decrease in the mean number of leaflets/plant was observed in the 6th week. This would be linked to the necrosis which was amplified by the accumulation of pollutants, thus favoring the fall of leaflets.

\section{Conclusion}

The effects of water pollution are real and affect the growth of plants. The results obtained indicate that there is a significant difference in some growth parameters of crop plants in polluted areas. Also, pollutants affect the level of chlorophylls in plants, decreasing its content in leaves and this is only visible through chlorosis spots, the darker coloration of the leaves and necrosis. Finally, trace elements such as Cadmium are found in large quantities proportional to their availability in the waste waters. Moreover, the decrease in chlorophyll content in plant leaves by pollutants also reduces the photosynthetic yield linked to organic matter such as carbohydrate, proteins, and lipids in plants.

These different pollutants affect the qualities and quantities of plant products. Furthermore the pollutants might influence the growth of plants and chlorophyll content in leaves as they have been absorbed by these plants. These pollutants found in the reserve organs could affect the resulting food chain. However, the study has indicated that high concentrations of Cadmium contribute to reduce growth in plants.

\section{References}

[1] FEUMBA 2012. Projet MAFAD: Quantification et caractérisation des boues de vidange issues des villes de Douala et Yaoundé (Cameroun) et proposition de traitement.

[2] Noukeu N. A. et Priso R. J (2014). Environmental impact of waste water discharges from Fermencam. International Journal of Environmental Protection and policy; 2(5): 174178 .

[3] Noukeu N. A, Gouado I, Priso R. J, Ndongo D, Taffouo V. D, Dibong S. D. et Ekodeck G. E. (2016). Characterization of effluent from food processing industries and stillage treatment trial with Eichhornia crassipes (Mart.) and Panicum maximum (Jacq.). Water Resources and Industry volume 16, 1-18.

[4] Bemmo N., Njine T., Nola N. M. et Ngamga D. (1998). Technique utilisées au niveau des quartiers périurbains, pour l'évacuation des eaux usées et excrétas humains: proposition de systèmes appropriés. Yaoundé, Cameroun. $121 \mathrm{p}$. 
[5] Agarwal S. (2005). Caloric restriction augments ROS defense in S. cerevisiae, by a Sir $2 p$ independent mechanism. Free Radic Res 39(1): 55-62.

[6] Priso R. J., Taffouo V. D., Kenne M., Amougou A. et De Sloover J. R. (2000). A propos de l'utilisation de Commelinaceae comme indicateur de qualité des milieux aquatiques sci. Techno. Dev. 7 (1): 4-11.

[7] Tchiaze Y. A et Priso R. J (2016). Répartition et valorisation des macrophytes envahissants dans la region du Littoral (Cameroun) cas d'Eichhornia crassipes (mart) solmslambache. Journal of applied biosciences 100: 9522-9534.

[8] Buchez A., Dorigo U. et Rimet F. (2010). Surveillance des impacts environnementaux d'effluences aqueux de sites industriels par les diatomées dulçaquicoles. Etude Record $\mathrm{n}^{\circ} 07-1016 / 11.175 \mathrm{p}$.

[9] Spalding M, Kainuma M. et Collins L. (2010). World Atlas of Mangroves. The International Society for Mangrove Ecosystems, Okinawa, Japan.

[10] Bonnin A. (2003). Les macrophytes bioindicteurs de la qualité de l'eau dans l'Arence, rivière fortement anthropisé de l'agglomération de Limoges (Haute-Vienne). Thèse de pharmacie, Université de Limoges. 114 p.

[11] Bregnot E. (2007). Déterminisme Spatio-temporel des peuplements macrophytiques en grands cours d'eau Application à la Garonne et à la Dordogne. Thèse Doctorat, Université de Bordeaux 1. $322 \mathrm{p}$.

[12] Priso R. J., Dibong S. D., Tchinda M. C., Taffouo V. D. Ndongo D. et Amougou A. (2010). Impacts des eaux polluées sur la croissance, les teneurs en chlorophylles et substances organiques dans les feuilles de deux Poaceae. Int. J. Biol. Sci. A (4): 1122-1129.

[13] Taffouo V. D., Kouamou J. K., Ngalangue L. M. T., Ndjeudji B. A. N. et Amougou A. (2009). Effects of salinity stress on growth, ions partitioning and yield of some cowpea (Vigna ungiuculata L., walp) cultivars Int. J. Bot., 5 (2) (2009), pp. 135-143.

[14] Dajoz R. (2000). Précis d'écologie. 7ème édition, Paris, 610$615 \mathrm{p}$.

[15] Glockner S. (2000). Modélisation de pollution atmosphérique: Thèse d'état en science physique de l'ingénieur, Université de Bordeaux 1. $180 \mathrm{p}$
[16] Radoux M. (1995). Qualité et traitement des eaux. Institution des sciences de l'environnement, Univ Dakar, Sénégal. 327p.

[17] Raymond M., Chevillon C., Guillemand T., Lenomand T. et Pasteur Phil N. (1998). An overview of the evolution of overproduced esterases in the mosquito culex pipens vol. 353; 1376.

[18] Priso R. J. (1994). Contribution à l'identification des indicateurs écologiques de pollution dans les régions de Yaoundé et Douala. Thèse de doct 3ème cycle, Université de Yaoundé 1 Cameroun. $180 \mathrm{p}$.

[19] Masarovicova E. et Kral'ovak L. (2002) Negative effect of toxic metal on higher plants. In main building of the friendrich schiller university jena, macro and trace elements mengenund spuren element, workshop, 341-345.

[20] Priso R. J, Ondo-obiang B, Etame J. et Din N. (2015) Influence de la pollution sur la répartition et le comportement de la végétation dans quelques écosystèmes de la région de Kribi-Cameroun, sciences, technologie et developpement 16: 23-32.

[21] Kengne N. I. M. (2000). Evaluation d'une station d'épuration des eaux usées domestiques par lagunage à macrophytes. Yaoundé: performances épuratoires, développement et biocontrôle Diptères Culicidae. Thèse doct. 3ème cycle. Université de Yaoundé 1. Cameroun. 137 p.

[22] Frontier S. et Pichod-Viale. (1998). Ecosystèmes; structure, fonctionnement et évolution. 2eme édition Dunod, Paris. 447 p.

[23] Tan Wan-Neng, LI Zhi-An, QIU Jing, ZOU Bi, LI Ning-Yu, ZHUANG Ping et WANG Gang. (2011). Lime and Phosphate Could Reduce Cadmium Uptake by Five Vegetables Commonly Grown in South China. ISSN 1002-0160/CN 321315/P Pedosphere 21(2): 223-229.

[24] Trocmé S. (1987). Le phosphore. in: keilling J. (edition) climat et sol techniques agricoles, Paris, pp 1240-1249.

[25] Abdul G. et Abdul W. (2007). Varietal differences for cadmium-incluced seedling mortality and foliar toxicity symptoms in mungbean (Vigna radiata). Int. j. Agr. A. 06-04 pp. 555-558.

[26] Agendia P. L. (1995). Treatement of sewerage using aquatic plant: case of Biyem-Assi domestic sewerage (Yaounde). Doctorat d'Etat thesis University of Yaounde I 168p. 